\title{
Maturation of the rat small intestine at weaning: changes in epithelial cell kinetics, bacterial flora, and mucosal immune activity
}

\author{
A G CUMmins, $T$ W SteEle, $J$ T LabROOY, AND $D$ J C SHEARMAN \\ From The Department of Medicine, University of Adelaide and Royal Adelaide Hospital and Department of \\ Microbiology, Institute of Medical and Veterinary Science, Adelaide, SA, Australia.
}

SUMMARY The relationship between maturation of the small intestine and change in mucosal immune activity was examined in the DA rat during the weaning period from 12 to 30 days. Two stages of jejunal maturation were observed: an initial stage of morphological development and crypt proliferation (days 12 to 22), followed by a period of stabilisation (days 24 to 30). By day 22 of the initial phase, villi increased principally in width but not in length, crypt length increased, and crypt cell production rate increased from 0.5 (day 12) to $11 \cdot 1$ (day 22) cells/crypt/hour. Various measures of mucosal immune activity showed a biphasic response. Up to days 20 to 22 , the weight of the mesenteric lymph node increased seven-fold $(p<0.0001)$, counts of jejunal eosinophils and goblet cells increased 3- $(p<0.0001)$ and 19 -fold $(p<0.0001)$ respectively, and mean serum rat mucosal mast cell protease II, released from mucosal mast cells, increased from 24 (day 12) to 313 (day 22) ng/ $\mathrm{ml}(\mathrm{p}<0 \cdot 0001)$. After day 22, mesenteric lymph node weight stabilised, eosinophil count stabilised and goblet cells decreased, serum rat mucosal mast cell protease II decreased three-fold $(\mathbf{p}<0 \cdot 0001)$, and mean jejunal count of intraepithelial lymphocytes increased from 26 (day 22) to 54 (day 24) cells per $\mathrm{mm}$ of muscularis mucosae $(\mathrm{p}<0 \cdot 0001)$, before stabilising. These results demonstrated a close association between maturation of the small intestine and change in activity of the mucosal immune system.

The small intestine in the rat undergoes a process of development and maturation that is associated with weaning; its weight increases from 15 days of age; and this is associated with lengthening of intestinal crypts and with increased cell proliferation. ${ }^{1}$ Interestingly, suckling and germ free animals have fewer intestinal lymphoid cells than adult animals, and their intestinal crypts are smaller and less active in proliferation. ${ }^{2-4}$ As cell mediated responses cause crypt lengthening and increased crypt cell production rate (CCPR) in enteropathies, ${ }^{5}$ it is possible that the effect of bacterial flora on mucosal morphology and epithelial cell proliferation is mediated by antigen driven activation of local $T$ cells. There have been no studies, however, to relate mucosal immune activity to change in bacterial flora and gut maturation during weaning.

Address for correspondence: Dr A G Cummins, Department of Medicine, Royal Adelaide Hospital, Adelaide, SA, 5000, Australia.

Received for publication 1 June 1988.
As it is difficult to directly measure cellular immune activity in the gut, surrogate measures need to be used such as jejunal count of intraepithelial lymphocytes (IEL) and crypt lengthening. These are characteristic of a delayed type hypersensitivity reaction that accompanies graft versus host reaction (by definition cell mediated), intestinal allograft rejection, and protein fed antigen immunisation. ${ }^{56}$ These are particularly useful when the putative antigenic stimulus is unknown. Further measures are also available in the rat, as expansion of mucosal mast cells (MMC) ${ }^{7}$ and goblet cells ${ }^{8}$ are known to be T cell mediated, while systemic release of rat mucosal mast cell protease II (RMCPII) from MMC serves as an activation marker that is raised during graft versus host reaction, ${ }^{9}$ although RMCPII is also released by an IgE mediated mechanism during anaphylaxis. ${ }^{10}$ Eosinophils have also been shown to be under $\mathrm{T}$ cell influence systemically, ${ }^{\text {" }}$ although a similar effect has not been studied in the small intestine. Jejunal counts of IEL, MMC, goblet cells, and eosinophils, and 
serum RMCPII estimation were therefore used as surrogate measures of mucosal cell mediated immune activity.

The aim of this study was to relate development of the small intestine from 12 to 30 days of age to changes in mucosal immune activity in the rat. This period was chosen to encompass pre- and postweaning events. Intestinal maturation was measured by intestinal morphology, epithelial cell kinetics, and activity of disaccharidase and alkaline phosphatase enzymes. We also examined colonisation of the small intestine by carrying out Gram stains and culture on gut washings.

\section{Methods}

RATS

Groups of six DA rat pups aged 12, 14, 16, 18, 20, 22, $24,26,28$, and 30 days were selected from litters of approximately the same size, although runted animals were excluded. Guidelines for animal experimentation of the National Health and Medical Research Council of Australia were followed.

PROCEDURES ON DAY OF KILLING

A group of pups was anaesthetised with ether and injected ip with vincristine $(1 \mathrm{mg} / \mathrm{kg})$. This initial injection was given at approximately $0900 \mathrm{~h}$. Animals were reanaesthetised at progressive time intervals after injection and exsanguinated by decapitation or from the axillary artery. Blood was collected for serum RMCPII estimation. The small intestine was removed under aseptic conditions and the length recorded after gently stretrhing the intestine at a 30 degree angle. Three 0.5 un jejunal segments were taken (the first at $10 \mathrm{~cm}$ from the pylorus and the other two in succession proximally) and orientated onto cardboard. One sample was fixed in Clarke's fixative $(75 \%$ ethanol: $25 \%$ acetic acid, v/v) with shaking for microdissection (the exact elapsed time was recorded since vincristine injection), another in Carnoy's fixative for MMC counts, and the third in freshly prepared $4 \%$ paraformaldehyde/phosphate buffered saline $(\mathrm{pH} \mathrm{7.4)}$. Three $\mathrm{cm}$ of adjacent proximal intestine was frozen for disaccharidase assays. The $\mathrm{mr}$ enteric lymph node (MLN) and spleen were removed and weighed. A further length of jejunum was removed at 10 to $20 \mathrm{~cm}$ from the pylorus under aseptic conditions and used to prepare gut washings for bacterial counts.

\section{MESENTERIC LYMPH NODE AND SPLEEN} WEIGHTS

The MLN of each animal was carefully dissected from the root of the mesentry of each animal and weighed. Spleens were removed and weighed.
BACTERIAL COUNT OF THE JEJUNUM Using a sterile 19 gauge hypodermic needle and a 10 $\mathrm{ml}$ plastic syringe, $5 \mathrm{ml}$ sterile $0 \cdot 15 \mathrm{M}$ sodium chloride was washed through $10 \mathrm{~cm}$ of jejunum, followed by 5 $\mathrm{ml}$ air, and collected from the distal end into a sterile Universal container. A drop of residual gut washing was examined as a wet film for protozoa. Five millilitre gut washing (neat and 1/10 dilution) was poured onto a preweighed blood agar Petri dish for aerobic culture, and drained onto a similar blood agar Petri dish for anaerobic culture. Both Petri dishes were reweighed to determine the innoculating volume. Agar plates were incubated overnight $\left(37^{\circ} \mathrm{C}\right)$ for aerobic culture and for $48 \mathrm{~h}$ for anaerobic culture. The total number of colonies was counted on each plate. As the innoculating volume of gut washing was known, bacterial count was expressed as organisms per ml of gut washing, as enumerated by colony forming units. After incubation, Gram stains were made from representative colonies on each plate. A small area of small intestine at $21 \mathrm{~cm}$ from the pylorus was opened and smeared onto a microscope slide for Gram stain of mucosal smears.

INTESTINAL MORPHOLOGY AND EPITHELIAI

CELL KINETICS

Intestinal tissue was fixed in Clarke's fixative overnight and stored in $70 \%$ ethanol. For microdissection, stored tissue was rehydrated, and hydrolysed for eight minutes in $1 \mathrm{M}$ hydrochloric acid at $60^{\circ} \mathrm{C}$ before staining with Feulgen reagent (\# 8542.88, Difco, Surrey, UK) for 40 minutes. Fragments of tissue were microdissected using a stereomicroscope, and examined after mounting in $45 \%$ acetic acid. Using a calibrated graticule, the length and maximal basal width of 15 villi, and length of 15 crypts were measured. The number of metaphases was counted in 15 crypts. This was used to calculate the CCPR from the rate of accumulation of metaphases after vincristine injection using a regression line of least squares estimate. ${ }^{12}$ The remaining Feulgen stained tissue was mounted in $45 \%$ acetic acid between two microscope slides and the ratio of the number of crypts to villi determined under microscopy using a square graticule.

JEJUNAL COUNTS OF EOSINOPHILS, IEL, GOBLET CELLS AND MMC

Intraepithelial lymphocyte goblet cells and MMC counts were carried out on jejunal tissue fixed in Carnoy's fixative, while eosinophil counts were done on tissue fixed in $4 \%$ paraformaldehyde/phosphate buffered saline. Tissues were embedded in paraffin, and histological sections cut at $4 \mu \mathrm{m}$. Haematoxylin and eosin was used to stain IEL and goblet cells, Alcian blue ( $\mathrm{pH} 0 \cdot 6) /$ safranin was used to stain for 
MMC, and carbol chromotrope was used to stain eosinophils. Cell counts were enumerated using a linear microscopic graticule $(323 \mu \mathrm{m}, \times 25$ objective lens) aligned along the muscularis mucosae of each sample. An average of 10 counts was obtained for each animal. All counts were expressed as cells per $\mathrm{mm}$ of muscularis mucosae.

\section{DETERMINATION OF SERUM RMCPII}

A solid phase antigen capture sandwich enzyme linked immunosorbent assay (ELISA) was used. ${ }^{13}$ The assay was developed by Dr J Huntley, Moredun Research Institute, Edinburgh, UK. Microtitre plates were coated overnight with sheep IgG antiRMCPII $(1 \mu \mathrm{g} / \mathrm{ml}$ in carbonate/bicarbonate buffer, $\mathrm{pH} \mathrm{9.6).} \mathrm{After} \mathrm{washing,} \mathrm{RMCPII} \mathrm{standards} \mathrm{(25-100}$ $\mathrm{ng} / \mathrm{ml}$ ) and dilutions of samples were added in duplicate for one to two hours. After incubation and washing, affinity purified sheep $F\left(a^{\prime}\right)_{2}$ antiRMCPII peroxidase conjugate $(1 / 4000)$ was added for one to two hours, and a colour reaction developed using $o$-phenylenediamine/hydrogen peroxide substrate. RMCPII concentration was read from the standard curve and expressed as $\mathrm{ng} / \mathrm{ml}$.

DISACCHARIDASE AND ALKALINE

PHOSPHATASE ASSAYS

A $3 \mathrm{~cm}$ segment of small intestine was homogenised $(1: 9 \mathrm{w} / \mathrm{v})$ in $0.15 \mathrm{M}$ potassium chloride and centrifuged at $800 \mathrm{~g}$ for 15 minutes before freezing at $-20^{\circ} \mathrm{C}$ for storage. Disaccharidase ${ }^{14}$ and alkaline phosphatase assays ${ }^{15}$ were modified to use microtitre 96-well ELISA plates and so that they could be read spectrophotometrically by an ELISA reader. For lactase (EC 3.2.1.23), sucrase (EC 3.2.1.48), and maltase assays, $50 \mu \mathrm{l}$ homogenate was incubated $(1 / 2,1 / 4,1 / 10)$ with the appropriate disaccharide

Table 1 Body weight, intestinal length and morphology of $D A$ rats during weaning from 12 days of age

\begin{tabular}{|c|c|c|c|c|c|c|}
\hline $\begin{array}{l}\text { Age } \\
\text { (day) }\end{array}$ & $\begin{array}{l}\text { Body } \\
\text { weight } \\
(g)\end{array}$ & $\begin{array}{l}\text { Intestinal } \\
\text { length } \\
(\mathrm{cm})\end{array}$ & $\begin{array}{l}\text { Villus } \\
\text { length } \\
(\mu \mathrm{m})\end{array}$ & $\begin{array}{l}\text { Villus } \\
\text { width* } \\
\text { ( } \mu \mathrm{m})\end{array}$ & $\begin{array}{l}\text { Crypt } \\
\text { length } \\
(\mu \mathrm{m})\end{array}$ & $\begin{array}{l}\text { Crypt:villus } \\
\text { ratio' }\end{array}$ \\
\hline 12 & $17 \cdot 7(2 \cdot 7)$ & $45(3)$ & $637(85)$ & $338(93)$ & $59(6)$ & $5 \cdot 9(0.9)$ \\
\hline 14 & $23.8(0.9)$ & $43(6)$ & $701(85)$ & $322(58)$ & $63(5)$ & $9 \cdot 0(2 \cdot 3)$ \\
\hline 16 & $24 \cdot 5(0.9)$ & $42(2)$ & $670(74)$ & 342 (27) & $67(7)$ & $9 \cdot 2(2 \cdot 3)$ \\
\hline 18 & $25 \cdot 2(1 \cdot 1)$ & $43(3)$ & $660(40)$ & $390(56)$ & $73(6)$ & $9 \cdot 6(1 \cdot 3)$ \\
\hline 20 & $28 \cdot 3(1 \cdot 7)$ & $50(2)$ & $715(89)$ & 459 (67) & $90(6)$ & $10 \cdot 1(2 \cdot 3)$ \\
\hline 22 & $29.0(1.7)$ & $53(1)$ & $689(84)$ & $452(81)$ & $101(7)$ & $11 \cdot 7(1 \cdot 1)$ \\
\hline 24 & $43 \cdot 1(3 \cdot 0)$ & $73(2)$ & $793(27)$ & $638(29)$ & $141(9)$ & $12 \cdot 5(1 \cdot 6)$ \\
\hline 26 & $49.7(2.9)$ & $79(2)$ & $680(24)$ & $585(36)$ & $140(8)$ & $12.4(2.9)$ \\
\hline 28 & $52 \cdot 7(5 \cdot 6)$ & $81(2)$ & 701 (29) & $554(64)$ & $150(10)$ & $13.0(2.9)$ \\
\hline 30 & $64 \cdot 6(4 \cdot 0)$ & $86(3)$ & $745(35)$ & $581(62)$ & $163(10)$ & $13.9(1.2)$ \\
\hline
\end{tabular}

*Maximal basal villus width; $†$ This is the ratio of the number of crypts/number of villi per unit area. Each age interval has the mean (SD) of six animals. substrate for 60 minutes. A colour reaction was developed with these samples $(10 \mu \mathrm{l}, 1 / 20$ dilution $)$, and with individual disaccharide blanks, as well as with a glucose standard curve $(125-750 \mu \mathrm{M})$ using glucose oxidase reagent. Disaccharidase activity was expressed as $\mu \mathrm{mol}$ of disaccharide hydrolysed $/ \mathrm{min} / \mathrm{g}$ wet weight of jejunum. For the alkaline phosphatase (ED 3.1.3.1) assay, gut homogenate was diluted, added $(25 \mu l, 1 / 100)$ to $100 \mu l \quad p$-nitrophenol phosphate substrate $(0.15 \mathrm{M})$ on an ELISA plate, and incubated for 30 minutes before being read. Alkaline phosphatase activity was expressed as $\mu \mathrm{mol}$ of nitrophenol phosphate hydrolysed/minute/g wet weight of jejunum. Neither disaccharidase and alkaline phosphatase activities were related to $\mathrm{g}$ protein to avoid assumptions about the relationship of enzyme activity to total protein.

STATISTICAL ANALYSIS

One way analysis of variance was used to test for significance difference of various group measures against time of weaning. Where necessary, individual paired comparisons were made using Peritz' $F$ test using a $95 \%$ experimentwise confidence interval. ${ }^{16}$ Where data displayed a skewed distribution, a $\log (\mathrm{x})$ transformation was done to normalise the distribution and stabilise the variance before significance testing. Crypt cell production rate was calculated from the least squares estimate of the linear regression of number of blocked metaphases with time after vincristine injection. Both Peritz' F test and CCPR were computed using programs adapted for the Apple Macintosh computer.

\section{Results}

GENERAL FEATURES

Rats pups opened their eyes after 18 days of age as they started to become less dependent on the dam rat. At the time of killing, milk was present in the gut of these pups, but decreased in volume and consistency by days $20-22$. By day 22 , formed faeces was present in the distal small intestine and large intestine.

\section{BODY WEIGHT AND INTESTINAL LENGTH}

Body weight and intestinal length are given in Table 1. Weaning was associated with an increase in these measures.

SPLEEN AND MESENTERIC LYMPH NODE

WEIGHTS

Spleen weight did not significantly increase over days 12 to 18 - for example, day $12 v$ day $18, \mathrm{p}=0 \cdot 29$, but increased after this time (Fig. 1). In contrast, MLN weight increased three-fold from days 12 to 18 


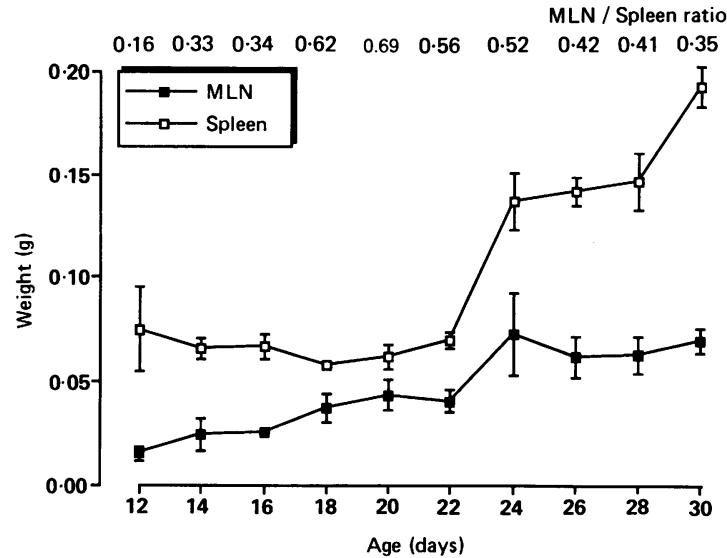

Fig. 1 Development of the spleen and mesenteric lymph node during weaning in the DA rat from 12 days of age. Each age interval represents the mean (SD) of six rats.

$(\mathrm{p}<0.0001)$; it reached a maximum weight with a seven-fold increase by day 24 ( $v$ day $12, \mathrm{p}<0.0001$ ), and stabilised with no significant change to day 30 (Fig. 1). The ratio of MLN weight to spleen weight remained low before weaning, but increased to a peak on day 20 , before falling to a value which remained higher than the preweaned ratio.

\section{BACTERIAL COUNT OFGUT WASHING AND DIRECT MICROSCOPY}

In preweaned animals, direct Gram stain and culture revealed only Gram positive bacilli, morphologically resembling Lactobacilli, and cocci. Five colony types of bacteria could be distinguished. During weaning, the total number of gut bacteria (colony forming units) decreased by $2 \log _{10}$ units to reach a nadir at day 18 of age, and increased again by $2 \log _{10}$ units to a plateau value by day 24 . Gram negative organisms were first identified on day 18 by Gram stain of mucosal smears and by culture of gut washing. Approximately 16 different species of bacteria could be distinguished from about day 20 , using such criteria as Gram staining and colony morphology. Occasional fungi were also seen on direct Gram stain and were grown on culture from day 22 . No protozoa were observed on direct wet film examination of gut washing.

\section{INTESTINAL MORPHOLOGY AND EPITHELIAL}

CELL KINETICS

Twelve day old rat pups had finger shaped villi. During weaning, the width of the villi increased as they became more leaf shaped. Intestinal crypts were small before weaning and lengthened during the period from about 16-18 days. Enterocytes of

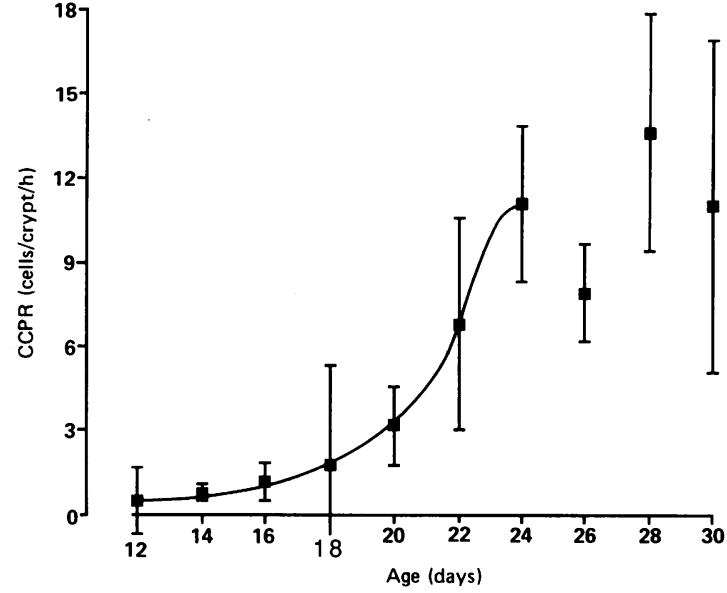

Fig. 2 Crypt cell production rate (CCPR) of the small intestine is given during weaning from days 12 to 30 . CCPR was measured from the regression slope of accumulation of metaphases in crypts with time after vincristine injection. The CCPR and $95 \%$ confidence interval were calculated for each age group of six rats.

suckling animals contained lipid droplets up to 20-22 days. Quantitative morphological measurements are given in Table 1 . Villus length increased slightly by day 24 ( $v$ day $12, \mathrm{p}=0.025)$, but otherwise there was no significant alteration. Maximal basal width of villi and intestinal crypt length increased but in both cases the principal increase occurred up to day 24 . Epithelial cell kinetics, measured by CCPR (Fig. 2), increased approximately 22 -fold from days 12 to 30 . An exponential increase in CCPR occurred up to day 24 , whereas values fluctuated after this time before stabilising.

\section{JEJUNAL COUNTS OF EOSINOPHILS, IEL, AND}

GOBLET CELLS

Counts of eosinophils, IEL, and goblet cells are given in Figure 3. Eosinophils began to increase after day 18 - for example, day $18 v 20, \mathrm{p}<0.0001$, and reached a 3-fold peak by day $24(\mathrm{p}<0.0001)$ before stabilising. On days $12-14$, the majority of eosinophils were located in the lamina propria, usually around the basal portion of the villi or in the pericryptal region, but some eosinophils were seen in an intraepithelial position after day 16 , and showed a distribution that was more uniform along the whole villus length. Intraepithelial lymphocytes increased by $50 \%$ from day 12 to day $22(p=0.0032)$, by two-fold at day 24 $(\mathrm{p}<0 \cdot 0001)$, and then remained stable until day 30 . Goblet cells increased exponentially 19-fold during the weaning period until day 24 , and decreased slightly until day 30 . Thus, both eosinophils and 

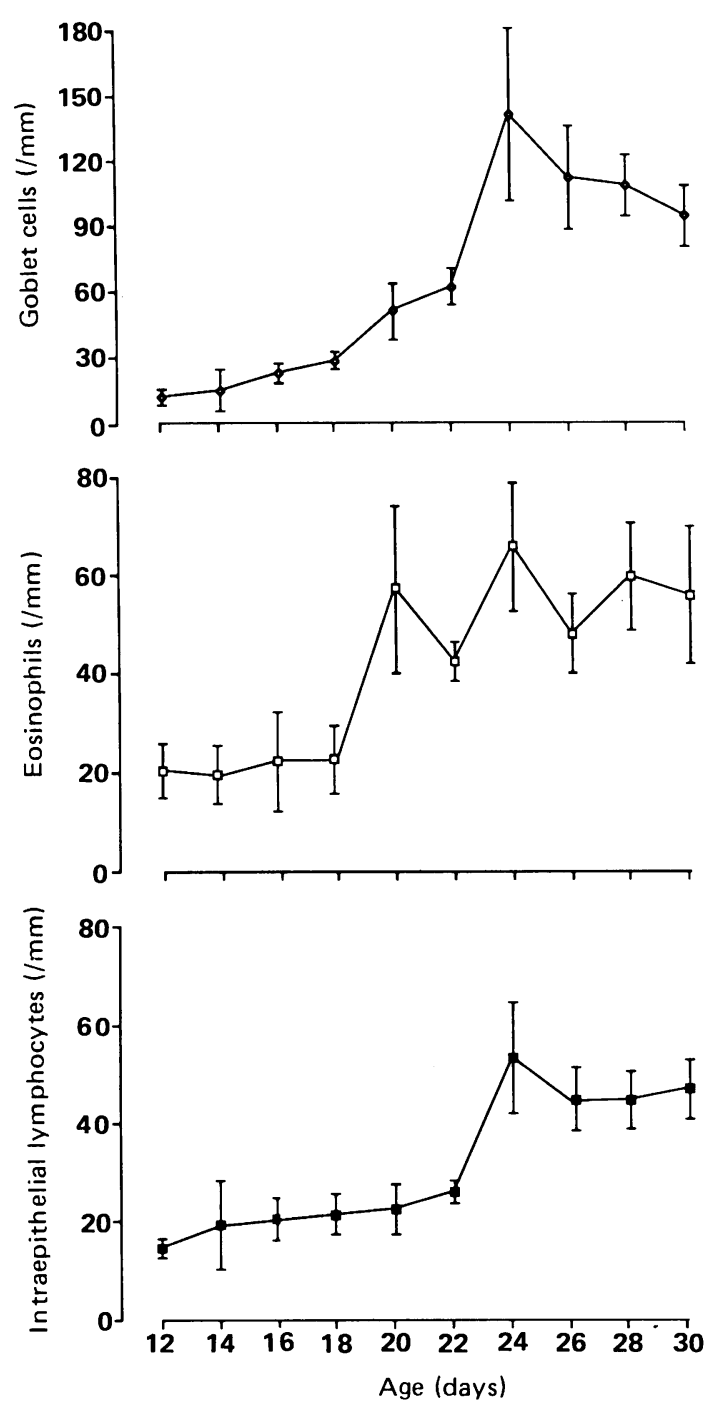

Fig. 3 Intestinal counts of goblet cells, eosinophils, and intraepithelial lymphocytes in DA rats during weaning from 12 days of age. Each age interval has the mean $\pm S D$ of six rats.

goblet cells increased up to day 24 , and later either stabilised or declined, while IEL had an abrupt and delayed two-fold rise to a more or less stable value at day 24.

\section{MUSOCAL MAST CELLS AND SERUM RMCPII} CONCENTRATION

Mucosal mast cells showed no significant increase until day 22 (Fig. 4), but there was a progressive loss of granule staining during this time, with fewer and smaller granules being present. Serum RMCPII

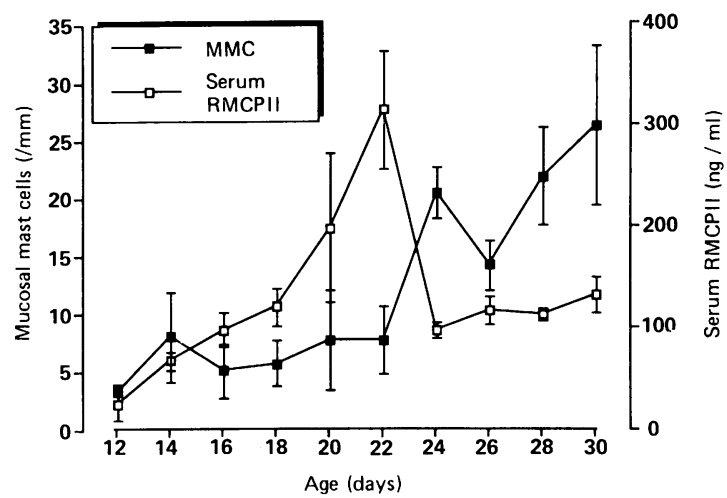

Fig. 4 Mucosal mast cell count in the small intestine and serum RMCPII concentration in DA rats during weaning from 12 days of age. Each age interval has the mean $\pm S D$ of six rats.

increased approximately five-fold from days 12 to 22 , indicating that the appearance of the granules was caused by sustained degranulation. From day 22 to 24 , MMC increased three-fold $(\mathrm{p}<0.0001)$, and granules increased in number and intensity of staining. The was associated with a three-fold fall in serum RMCPII to adult values, indicating a decrease in MMC activation.

DISACCHARIDASE AND ALKALINE

PHOSPHATASE ASSAYS

Results of disaccharidase and alkaline phosphatase assays are given in Table 2. Lactase activity was maintained during the suckling period from day 12 to 20 , but decreased as spontaneous weaning occurred. Sucrase and maltase showed low activity before day 18 , and increased before stabilising after day 24 .

Table 2 Disaccharidase and alkaline phosphatase activities of the small intestine in DA rats during weaning from 12 days of age

\begin{tabular}{lllcl}
\hline Age & Lactase* $^{*}$ & Sucrase* $^{*}$ & Maltase* $^{*}$ & $\begin{array}{l}\text { Alkaline } \\
\text { phosphatase }\end{array}$ \\
\hline 12 & NA $\ddagger$ & 0 & $3(4)$ & $34(15)$ \\
14 & $1 \cdot 3(0 \cdot 4)$ & 0 & $7(11)$ & $39(15)$ \\
16 & $1 \cdot 4(0 \cdot 4)$ & 0 & $8(7)$ & $48(11)$ \\
18 & $1 \cdot 4(0 \cdot 4)$ & $0 \cdot 6(1 \cdot 0)$ & $22(6)$ & $55(17)$ \\
20 & $1 \cdot 5(1 \cdot 5)$ & $6 \cdot 8(3 \cdot 0)$ & $68(21)$ & $84(16)$ \\
22 & $0 \cdot 7(0 \cdot 6)$ & $4 \cdot 0(2 \cdot 3)$ & $51(20)$ & $62(22)$ \\
24 & $0 \cdot 5(0 \cdot 5)$ & $4 \cdot 3(2 \cdot 3)$ & $75(38)$ & $78(16)$ \\
26 & $0 \cdot 8(0 \cdot 7)$ & $2 \cdot 6(1 \cdot 3)$ & $108(14)$ & $71(8)$ \\
28 & $0 \cdot 3(0 \cdot 3)$ & $2 \cdot 9(1 \cdot 1)$ & $79(18)$ & $60(11)$ \\
30 & $0 \cdot 2(0 \cdot 1)$ & $2 \cdot 9(0 \cdot 9)$ & $82(13)$ & $33(13)$ \\
\hline
\end{tabular}

*One unit $=\mu \mathrm{mol}$ of disaccharide hydrolysed $/ \mathrm{min} / \mathrm{g}$ wet weight; †One unit $=\mu \mathrm{mol}$ of nitrophenol phosphate hydrolysed $/ \mathrm{minute} / \mathrm{g}$ wet weight. Each age interval has the mean (SD) of four to six animals; $\ddagger$ Not available. 
Alkaline phosphatase increased to a broad peak centred over the mid-weaning period (days 20-26).

\section{Discussion}

During weaning, we have described an increase in MLN weight and in jejunal counts of MMC, IEL, eosinophils and goblet cells, and systemic release of RMCPII. These changes were associated with morphological development and crypt cell proliferation and stabilisation. Intestinal maturation was confirmed by changes in disaccharidases and some increase in alkaline phosphatase activity.

Mesenteric lymph node and spleen weights were used as indicators of enteric or systemic immune activity on the principle that a draining lymphoid organ reflects immune activation in the region. In unpublished work, we have recently shown that feeding protein antigen to mice causes increase in MLN weight and reciprocal decrease in spleen weight, and that this is associated with a delayed type hypersensitivity reaction in the MLN as measured by an indirect footpad test. Thus the change in MLN weight in this study provides evidence of increased enteric immune activity during weaning.

We believe that systemic release of RMCPII from MMC indicated mucosal $\mathrm{T}$ cell activity. Evidence for this is that a raised serum RMCPII is a sensitive indicator of mucosal graft versus host reaction, ${ }^{9}{ }^{1718}$ which is the exemplary model of a $T$ cell mediated reaction. In addition, the $T$ cell suppressive agent, cyclosporin A, causes a $90 \%$ fall in serum RMCPII concentration in normal adult rats ${ }^{18}$ implying basal immune stimulation of MMC under physiological conditions. Although MMC are also stimulated by IgE during anaphylaxis, ${ }^{111}{ }^{13}$ this is associated with an increase in intestinal permeability, ${ }^{10}$ rather than a decrease in permeability which occurs during weaning. ${ }^{19}$ Apart from moderate activity of substance $\mathrm{P}, \mathrm{MMC}$ are distinguished from connective tissue mast cells by being remarkably resistant to a wide range of secretagogues, such as polyamines and neuropeptides. ${ }^{20}$ While we cannot altogether exclude a stimulatory effect of substance $P$ and other unknown factors, this is unlikely as we have recently shown that cyclosporin A delays intestinal maturation (unpublished observation), again suggesting that a $T$ cell dependent mechanism may be involved. Moreover, any other mechanism would fail to explain stimulation followed by suppression of RMCPII secretion. Serum RMCPII originates from intestinal MMC, because MMC are preferentially distributed to the gut. ${ }^{21}$ This systemic release of RMCPII during weaning confirms a previous study.22

All measures of immune activity showed a biphasic response. Thus, MLN weight increased seven-fold up to day 20 and subsequently fell slightly; jejunal cell counts of eosinophils and goblet cells increased until day 24, before stabilising or falling; MMC were activated up to day 22 , and this was followed by relative suppression; and IEL were initially low and later showed a delayed rise at day 24 . These various measures support the notion that weaning was associated with sequential activation and later suppression of the mucosal immune system. A possible mediator of this suppression of mucosal immune activation could be IEL. Perhaps this is the functional role for IEL during delayed type hypersensitivity reactions in the gut, where their numbers are increased and it could be consistent with their OX8/CD8 cytotoxic/ suppressor phenotype..$^{23}$ Some caution is necessary, however, because the nature and in vivo function of IEL is unknown..$^{24}$ An alternative suppressor system is activated macrophages. ${ }^{25}$

Mucosal mast cell count and serum RMCPII measurement enabled us to identify activation of $\mathrm{MMC}$ in the period from day 16 to 22 , even though the MMC count apparently remained stationary. The exponential rise in serum RMCPII showed that this low count was caused by intense degranulation and not low activity. This was also evident in the progressive loss of granule staining in those MMC that remained visible on staining during this period. Thus, although MMC are expanded in immunologically mediated reactions in the gut, a caveat must be added that the apparent number of MMC may fall under intense stimulation. This is also seen in severe graft versus host reaction in rats and contrasts with milder reaction in which MMC increase and serum RMCPII shows a small rise. ${ }^{4}$

Measurement and expression of the denominator in cell counts of the intestines remain controversial. This reflects the difficulty in defining an invariable reference, whether it be expressed per 100 epithelial cells, per villus/crypt unit, per $\mathrm{mm}^{2}$ of mucosa, per $\mathrm{mm}$ or area of muscularis mucosae. Marsh ${ }^{26}$ has advised expressing counts per area of muscularis mucosae but this assumes that the muscularis mucosae remains unaltered. This assumption seems unjustified particularly during weaning or with protein deficiency, ${ }^{13}$ because it is likely the muscularis mucosae does alter. Thus, the use of this denominator would seem to have no advantage in these situations. We have chosen, therefore, to rely on differences in cell counts being far greater than any change in muscularis mucosae, and to express cell counts per mm of muscularis mucosae, which can be easily measured using a microscopic graticule.

It is interesting that morphological change and increase in CCPR was synchronous with some changes in mucosal immune activity, such as increase in MLN weight and systemic release of RMCPII from 
MMC. In particular, CCPR and serum RMCPII showed an exponential rise from days 12 to 22 , before both stabilised. As heightened $\mathrm{T}$ cell activity in neonatal graft versus host reaction ${ }^{27}$ is known to induce precocious intestinal maturation (before evolving into enteropathy), this would indicate that crypt proliferation may be controlled by $\mathrm{T}$ cell activity. This is also supported by the observation that $T$ cell deficient (nude) mice have smaller intestinal crypts and lower CCPR than conventional mice, ${ }^{28}$ again suggesting that $\mathrm{T}$ cell activity affects crypt proliferation. Our results would extend this concept to the physiological process of weaning maturation. The mucosal immune system may have been activated by bacterial flora that developed before weaning. In addition, there may have been some contribution to mucosal stimulation from food antigens either actively ingested or passively absorbed in the dam's milk. As Ferguson ${ }^{29}{ }^{30}$ has shown that maturation is partly genetically preprogrammed, we would envisage that this physiological immune reaction would advance this preprogrammed rate of intestinal development.

Although it is known that preweaned animals have Gram positive bacteria, and later Gram negative bacteria appear during or after weaning, ${ }^{31}$ our results showed the timing of this change in relationship to immune activity and intestinal maturation. Gram negative bacteria were not identified either on Gram stain of mucosal smears or by culture of gut washing before day 18. It is possible that colonisation with Gram negative bacteria was responsible for activating the suppressive immune phase, leading in turn to stabilisation of maturation. This is suggested because bacterial colonisation of germ free animals generates suppressor cells. ${ }^{25}$

After day 24 , the CCPR fluctuated with positiye and negative swings as it stabilised suggesting that a negative feedback system was operating, although it is not possible to completely exclude an effect of random variation. The presence of such a negative feedback system would, however, still be necessary to explain stabilisation of exponential rise in crypt cell proliferation after day 24 . The presence or absence of fluctuations is not crucial to demonstration of a negative feedback system, as these would be dependent on the degree of dampening of the system. A negative feedback system has already been shown in the intestine during the recovery phase of adult mice treated with cytarabine by Wright and AlNafussi..$^{32}$ Although the previous authors ${ }^{3}$ have also made a careful study of cell kinetics during weaning in the mouse, their study was terminated before maximum CCPR was achieved (at $70 \%$ of adult values), and hence fluctuations (if present) were not observed.
Taken together, our results suggest that maturation of the small intestine during weaning is controlled in part by activation of the mucosal immune system. The latter may be because of the development of bacterial flora or to the presence of food antigens, and it may be followed by a period of immune suppression leading to a final stabilisation of crypt cell production to adult levels.

This work was presented in abstract form to the 17th Annual Meeting of the Australian Society for Immunology, Canberra, February 1988. Dr Cummins was supported during this study by a Dawes' Research Fellowship from Royal Adelaide Hospital. The authors are very grateful to Dr H R P Miller, Moredun Research Institute, Edinburgh, Scotland, who supplied immunoreagents used in the ELISA assay. We thank Dr R Rowland, Institute of Medical and Veterinary Science, who provided histological facilities. We greatly appreciate technical assistance of Miss S Clare, Mrs D Pyle, Mrs J Langman, Mr B Lewis, and staff of the Animal House of the Institute of Medical and Veterinary Science. We are very grateful to Drs G Mayrhofer and D Jewell for helpful discussions and comments on the manuscript.

\section{References}

1 Herbst JJ, Sunshine P. Postnatal development of the small intestine of the rat. Changes in mucosal morphology at weaning. Pediatr Res $1969 ; 3$ : 27-33.

2 Crabbe PA, Nash DR, Bazin H, Eyssen H, Heremans JF. Immunohistochemical observations on lymphoid tissues from conventional and germ-free mice. Lab Invest 1970; 22: 448-57.

3 Al-Nafussi AI, Wright NA. Cell kinetics in the mouse small intestine during immediate postnatal life. Virchows Arch [Cell Pathol] 1982; 40: 51-62.

4 Lee PC, Lebenthal E. Early weaning and precocious development of small intestine in rats: genetic, dietary of hormonal control. Pediatr Res 1983; 17: 645-50.

5 Ferguson Anne. Models of immunologically driven small intestinal damage. In: Marsh MN, ed. Immunopathology of the Small Intestine. Chichester: John Wiley \& Co Ltd, 1987: 225-52.

6 Mowat AMcI, Ferguson Anne. Intraepithelial lymphocyte count and crypt hyperplasia measure the mucosal component of the graft-versus-host reaction in mouse small intestine. Gastroenterology 1982; 83: 417-23.

7 Mayrhofer G, Fisher R. Mast cells in severely T-cell depleted rats and the response to infestation with Nippostrongylus brasiliensis. Immunology 1979; 37: 145-55.

8 Miller HRP, Nawa Y. Nippostrongylus brasiliensis: Intestinal goblet cell response in adoptively immunized rats. Exp Parasitol 1979; 47: 81-90. 
9 Cummins AG, Munro GH, Miller HRP, Ferguson Anne. Separate effects of irradiation and graft-versushost reaction on mucosal mast cells in the rat. Gut 1988 , in press.

10 Patrick MK, Dunn IJ, Buret A, et al. Mast cell protease release and mucosal ultrastructure during intestinal anaphylaxis in the rat. Gastroenterology 1988; 94: 1-9.

11 Basten A, Beeson PB. Mechanism of eosinophilia. II. Role of the lymphocyte. J Exp Med 1970; 130: 1288-305.

12 Wright NA. The experimental analysis of changes in proliferative and morphological status on the intestine. Scand J Gastroenterol 1982; 74: 3-10.

13 Cummins AG, Kenny A, Duncombe VM, Bolin TD, Davis AE. The effect of protein deficiency on systemic release of rat mucosal mast cell protease II during Nippostrongyulus brasiliensis infection and following systemic anaphylaxis. Immunol Cell Biol 1987; 65: 35763.

14 Dahlqvist A. A method for assay of intestinal disaccharidases. Anal Biochem 1964; 7: 18-25.

15 Bessey OA, Lowry OH, Brock MJ. A method for the rapid determination of alkaline phosphatase with five cubic millimeters of serum. J Biol Chem 1946; 164: 321-9.

16 Harper JF. Pertiz' F test: BASIC program of a robust multiple comparison test for statistical analysis of all differences among group means. Comput Biol Med $1984 ; 14: 437-45$.

17 Ferguson Anne, Cummins AG, Munro GH, Gibson S. Mucosal mast cells in experimental GvHR. In: Hamelmann H, Deltz E, eds. Experimental and Clinical Fundamentals of Small Bowel Transplantation. Heidelberg: Springer-Verlag, 1986: 95-7.

18 Cummins AG, Munro GH, Ferguson Anne. The effect of cyclosporin A on rat mucosal mast cells and on the protease RMCPII. Clin Exp Immunol 1988; 72: 136-40.

19 Younoszai MK, Sapario RS, Laughlin M. Maturation of jejunum and ileum in rat. Water and electrolyte transport during in vivo perfusion of hypertonic solutions. J Clin Invest 1978; 62: 271-80.

20 Befus AD. Editorial. Intestinal mast cell polymorphism: New research directions and clinical implications. J Pediatr Gastroenterol Nutr 1986; 5: 517-21.

21 Gibson S, Mackellar A, Newlands GFJ, Miller HRP. Phenotypic expression of mast cell granule proteinases.
Distribution of mast cell proteinases I and II in the rat digestive system. Immunology 1987; 62: 621-7.

22 Cummins AG, Munro GH, Miller HRP, Ferguson Anne. Association of maturation of the small intestine at weaning with mucosal mast cell activation in the rat. Immunol Cell Biol. (In press.)

23 Mayrhofer G. Physiology of the intestinal immune function. In: Newby TJ, Stokes CR, eds. Local Immune Responses of the Gut. Boca Raton, Florida: CRC Press Inc, 1986: 1-96.

24 Mayrhofer G, Whately RJ. Granular intraepithelial lymphocytes of the rat small intestine. I. Isolation, presence in $\mathrm{T}$ lymphocyte-deficient rats and bone marrow origin. Int Arch Allergy 1983; 71: 317-27.

25 Mattingly JA, Eardley DD, Kemp JD, Gershon RK. Induction of suppressor cells in rat spleen: influence of microbial stimulation. J Immunol 1979; 122: 787-90.

26 Marsh MN. Studies of intestinal lymphoid tissue. III. Quantitative analysis of epithelial lymphocytes in the small intestine of human control subjects and of patients with celiac sprue. Gastroenterology 1980; 79: 481-92.

27 Lund EK, Bruce MG, Smith MW, Ferguson Anne. Selective effects of graft-versus-host reaction on disaccharidase expression by mouse enterocytes. Clin Sci 1986; 71: 189-98.

28 Mowat AMcI, Felstein MV, Baca ME. Experimental studies of immunologically mediated enteropathy. III. Severe and progressive enteropathy during graft-versushost reaction in athymic mice. Immunology 1987; 61: 185-8.

29 Ferguson Anne, Parrott DMV. Growth and development of 'antigen-free' grafts of fetal mouse intestine. J Pathol 1972; 106: 95-101.

30 Ferguson Anne, Gerskowitch VP, Russell RI. Preand post-weaning disaccharidase patterns in isografts of fetal mouse intestine. Gastroenterology 1973; 64: 292-7.

31 Savage DC. Microbial ecology of the gastrointestinal tract. Annu Rev Microbiol 1966; 51: 868-74.

32 Wright NA, Al-Nafussi A. The kinetics of villus cell populations in the mouse small intestine. II. Studies on growth control after death of proliferative cells induced by cytosine arabinoside, with special reference to negative feedback mechanisms. Cell Tissue Kinet 1982; 15: $611-21$ 